\title{
Response to neoadjuvant treatment in patients with breast cancer from the Department of Medical Oncology of the Hospital de Clínicas
}

\author{
Patricia Lorena Giménez-Martínez ${ }^{1 *}$ and Laura Emilce Flores-Rodríguez ${ }^{2}$ \\ ${ }^{1}$ Medical Oncologist at Hospital de Clínicas, Faculty of Medical Sciences, Universidad Nacional de Asunción; ${ }^{2}$ Teaching Researcher Physician, \\ Research for Development, Paraguay
}

\begin{abstract}
Introduction: Breast cancer is one of the most frequent malignant tumors in women; in Paraguay it has a high mortality. Neoadjuvant chemotherapy was introduced to reduce the size of the tumor and make resectables the tumors considered unresectables, allowing to perform conservative surgeries and test the sensitivity to chemotherapy. Material and methods: Descriptive study, transverse, retrospective and with analytical component. Sample: 130 patients with breast cancer who received neoadjuvant treatment in the Department of Medical Oncology of Hospital de Clínicas FCM-UNA from 2010 to 2016. Variables: age, sex, biological types, histological grade, histological type, lymphovascular permeation, clinical stage, clinical response, pathological response in the tumor $(T)$ and pathological response in the armpit $(N)$. The sampling was non-probabilistic due to the convenience of consecutive cases. Mean, frequency, and $\chi^{2}$ were used. Results: According to RECIST (Response Evaluation Criteria in Solid Tumors) 1.1 criteria, a higher frequency of partial response was found in $43.85 \%$, and according to Sataloff criteria for pathological response of T tumor, the highest frequency was T-C, in $37.5 \%$. Pathological response in the armpit N increased frequency of N-D in $36.46 \%$. The most frequent biological type was luminal $A$, in $31.54 \%$. In all molecular phenotypes, higher rates of pathological response in the breast compared to those in the axilla were observed. Rate of clinical and pathological response in breast $T$ was statistically significant depending on whether the treatment was complete or not $(p<0.05)$. Conclusion: Pathological response in the breast was greater than that found in the axilla. The HER2+ and the triple negative molecular subtypes had a higher response rate than the luminal.
\end{abstract}

Key words: Breast cancer. Neoadyuvancia. Paraguay.

\section{Correspondence:}

*Patricia Lorena Giménez-Martínez

E-mail: patyloregime@gmail.com

1665-9201/@ 2019 Sociedad Mexicana de Oncología. Published by Permanyer México. This is an Open Access article under the terms of the CC BY-NC-ND

Available online: 04-07-2019 Gac Mex Oncol. 2019;18:1-7 www.gamo-smeo.com
$\mathrm{ms}$ of the CC BY-NC-ND license (http://creativecommons.org/licenses/by-nc-nd/4.0/). 


\section{Introduction}

Breast cancer is one of the most common malignancies in women. Thanks to the enormous interest this topic has aroused, advances have emerged in all areas, from an increasingly earlier diagnosis to the proposal of a treatment that includes the rational use of multidisciplinary therapeutic maneuvers ${ }^{1}$.

Breast cancer is the second most common cause of death in the USA in women and the most common cause of death for women aged between 45 and 55 years $^{2}$. In Paraguay, according to data of the 2015 population-based cancer registry, breast cancer ranks first as a cause of mortality (324), with a mortality rate of $9.7 \%$ per 100 thousand. The Union for International Cancer Control (UICC) created a system for tumor staging, designed and implemented for the first time on breast cancer in 1959. The UICC and the American Joint Committee on Cancer (AJCC) unified their classifications more than one decade ago, creating a single $\mathrm{TNM}^{3-7}$ system. In recent years, using microarray techniques, the genetic profile of breast carcinomas has been studied, with a group of tumors that morphologically could be similar but with a different genetic profile being found. This is how the concept of molecular subtypes emerged. ${ }^{8}$ Subsequently, these subtypes were to be be characterized by immunohistochemical techniques, which allow detecting hormone receptor (estrogen and progesterone), HER2 and Ki67 status, with response prognostic and predictive value ${ }^{9,10}$. Taking these considerations into account, and according to hormone receptor, HER2 oncoprotein and Ki67 proliferation index status, we will define the molecular categories within the following subtypes by immunohistochemistry: luminal A, luminal B, luminal-HER2, HER2 and basal-like (the latter is the most common among the triple-negative subtypes) ${ }^{11-15}$.

Neoadjuvant chemotherapy, also known as induction chemotherapy or initial chemotherapy, as a therapy that is administered prior to surgical treatment, was introduced with the purpose to decrease tumor size and to try to make resectable tumors otherwise regarded as unresectable. Later, it was also used to enable the performance of conservative surgeries. It is applicable in large and locally advanced clinical stage III tumors and in some cases in stage II tumors. In addition, it provides information on tumor sensitivity to drugs. Another objective is to decrease local relapses and improve survival, due to the early treatment of micrometastases that are theoretically present at diagnosis ${ }^{16-18}$.
In 2000, the Response Evaluation Criteria in Solid Tumors (RECIST) were published, which were subsequently called RECIST 1.0 criteria, since they were revised in 2009 (RECIST 1.1 criteria). These criteria emerged as a modification of previous response criteria, establishing the definition of measurable and non-measurable lesions and of target and non-target lesions (always using a one-dimensional measure) and modifying the treatment response criteria ${ }^{19-21}$.

The definitive form to assess the response to neoadjuvant chemotherapy treatment is through anatomopathological examination of the surgical specimen. Although there are different criteria, in general terms we refer to pathologic complete response (pCR) when there is evidence of complete disappearance of the infiltrating component both in the breast and in the axiIla. The persistence of the intraductal component in the breast is considered, similarly, pCR ${ }^{22-34}$.

\section{Overall objective}

To determine the clinical and pathologic treatment responses of patients with breast cancer undergoing neoadjuvant treatment at Hospital de Clínicas Oncology Department during the 2010-2016 period.

\section{Specific objectives}

To assess the percentage of patients undergoing neoadjuvant treatment according to age, gender, histological type, histological grade, biological types, lymphovascular permeation, clinical stage and treatment received.

To analyze clinical and pathologic responses according to biological types, histological grade, clinical stage and type of received treatment.

To evaluate the relationship between clinical and pathologic response.

\section{Material and methods}

\section{Design}

Descriptive, cross-sectional, observational retrospective analysis with an analytical component. Sample: breast cancer patients who received neoadjuvant treatment at Hospital de Clínicas FCM-UNA Department of Medical Oncology within the 2010-2016 period. Variables: age, gender, biological types, histological grade, histological type, lymphovascular permeation, clinical stage, clinical response, tumor $(T)$ pathologic response 
and axillary (N) pathologic response. Non-probabilistic, convenience sampling of consecutive cases.

\section{Inclusion criteria}

Patients with breast cancer, with diagnosis confirmed by pathological anatomy, undergoing neoadjuvant treatment.

\section{Exclusion criteria}

Patients without breast cancer confirmation by pathological anatomy. Patients with distant metastasis at the beginning of treatment. Patients who underwent tumor resection prior to treatment. Patients not showing satisfactory therapeutic adherence.

\section{Data collection}

Clinical records meeting the inclusion criteria of the present study were collected.

\section{Measurement instruments}

Data were captured in an Excel ${ }^{\circledR}$ electronic spreadsheet. The results were represented in the form of tables and bar and pie charts. Clinical response was assessed using the RECIST criteria. For the measurement of tumor size, imaging methods such as contrasted computerized axial tomography and nuclear magnetic resonance imaging were used, whereas breast and axillary pathologic response was evaluated according to the Sataloff criteria. Immunohistochemistry with proliferation index based on percentages lower or higher than $14 \%$ was used for tumor molecular classification.

\section{Data analysis}

All data were extracted from the clinical records of those patients who met the inclusion criteria. Hundred and thirty adult patients of both sexes, with a histological diagnosis of breast cancer and undergoing neoadjuvant treatment, admitted to the Oncology Department (from March 2010 to December 2016) were included. The percentages were calculated using the Epiinfo ${ }^{\circledR} 7.2$ and Stata ${ }^{\circledR} 14$ computer programs. Mean, frequency and $\chi^{2}$ were used. The results were expressed in different graphs with circular format, columns, bars and rings, and tables were also generated, which facilitated the findings visualization; for their development, the Microsoft Excel $2010^{\circledR}$ and Stata ${ }^{\circledR} 14$ programs were used.

\section{Ethical aspects}

The information emerging from the study was confidentially handled. Permission was requested to access the clinical records by means of an authorization note addressed to the relevant authorities.

\section{Results}

In total, 130 clinical records of patients diagnosed with breast cancer undergoing neoadjuvant treatment were analyzed. According to RECIST 1.1 clinical response criteria, partial response was more common $(43.85 \%)$, followed by complete response $(34.62 \%)$, incomplete response $(12.31 \%)$ and progressive disease (9.23\%). According to the Sataloff criteria for tumor (T) pathologic response, T-C, which corresponds to a therapeutic effect lower than $50 \%$, was found more frequently in $37.5 \%$, followed by T-B, which corresponds to a therapeutic effect higher than $50 \%$ but not to total effect, was observed in $30.21 \%$; in third place, T-A, which corresponds to total or almost total therapeutic effect, was observed in $29.17 \%$, and the less common was T-D, which represents no therapeutic effect and was observed in $2.31 \%$. Following the same criteria, axillary pathologic response $(\mathrm{N})$ was evaluated, where $\mathrm{N}-\mathrm{D}$, which represents metastasis without changes secondary to chemotherapy was found more frequently $(36.46 \%)$, followed by $\mathrm{N}-\mathrm{B}$, which is equivalent to no secondary changes and no metastases and was observed in $31.25 \%$, followed by N-A, which represents changes secondary to chemotherapy without metastasis and was observed in $16.67 \%$, closely followed by $\mathrm{N}-\mathrm{C}$, which represents changes secondary to chemotherapy and metastasis and was observed in $15.63 \%$. Mean age was $52.85 \pm 12.6(30-85)$ years, with $17.69 \%$ of 40 years or younger, $57.1 \%$ between 41 to 60 years and $25.3 \%$ older than 60 years (Fig. 1). As for gender, females predominated, with $98.4 \%$.

According to histological type and grade, ductal tumors had a frequency of 116 cases $(89.23 \%)$, followed by lobular lesions $(9.23 \%)$ and by the "other" category $(1.54 \%)$, which included the mixed type; grade I was found in $0.77 \%$, grade II in $28.46 \%$, and the most commonly observed was grade III (70.77\%) (Fig. 2). The most common biological type was luminal $A$, with a rate of $31.54 \%$, followed by luminal B in $28.46 \%$, triple-negative in $17.69 \%$, HER2+ in $14.62 \%$ and luminal B-HER2+ in $7.69 \%$ (Fig. 3).

Of a total of 96 examined surgical specimens, $23.08 \%$ had lymphovascular permeation and in $76.92 \%$ the 


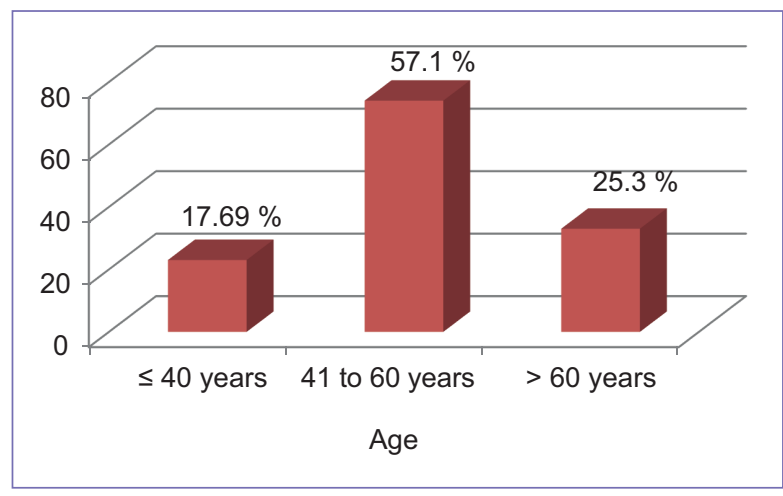

Figure 1. Frequency and percentage of patients diagnosed with breast cancer who received neoadjuvant treatment by age $(n=30)$.

data was not reported in the pathological anatomy report. Of the studied patients, $74.62 \%$ received complete treatment, in comparison with $25.38 \%$ who received incomplete treatment due to toxicity, disease progression or treatment withdrawal. The received treatment regimens were: the most common was Adriamycin + Cyclophosphamide (AC) + taxane in $53.08 \%$, followed by $A C$ in $23.08 \%, A C$ + taxane + trastuzumab in $12.31 \%$, $A C+$ platinum + taxane in $6.15 \%$, aromatase inhibitor in $3.85 \%$, platinum + taxane + trastuzumab and tamoxifen, both in $0.77 \%$. Regarding the relationship between clinical responses and biological types, among the subjects with the luminal A phenotype, 8 had a clinical complete response (19.51\%). The most common was partial response, which was observed in 24 patients (58.54\%), incomplete response was observed in seven (17.07\%) and progressive disease in two (4.88\%). Among the patients with the luminal $B$ molecular phenotype, 13 (34.14\%) had clinical complete response, $17(45.95 \%)$ had partial response, 4 (10.81\%) had incomplete response and three $(8.11 \%)$ had progressive disease. As for the women with luminal B-HER2+, out of 10 studied patients, $5(50 \%)$ had clinical complete response, $3(30 \%)$ had partial response, $2(20 \%)$ had incomplete response and no patient had progressive disease. Among the patients with the HER2+ subtype, clinical complete response was observed in nine $(47.37 \%)$, partial response in seven $(36.84 \%)$, no patient had incomplete response and progressive disease was observed in $3(15.79 \%)$. As for the patients with triple-negative breast cancer, clinical complete response was found in 10 patients (43.48\%), partial response in $6(26.09 \%)$, incomplete response in three (13.04\%) and progressive disease was observed in four, which
Table 1. Frequency and percentage of breast cancer-diagnosed patients who received neoadjuvant treatment by clinical response $(n=130)$

\begin{tabular}{|l|c|c|}
\hline Clinical response & Frequency & Percentage \\
\hline Complete & 45 & 34.62 \\
\hline Incomplete or SD & 16 & 12.31 \\
\hline Partial & 57 & 43.85 \\
\hline Progressive disease & 12 & 9.23 \\
\hline Total & 130 & 100.00 \\
\hline
\end{tabular}

SD: Stable disease

Table 2. Frequency and percentage of breast cancer-diagnosed patients who received neoadjuvant treatment by breast T pathologic response $(n=96)$

\begin{tabular}{|c|c|c|}
\hline T pathologic response & Frequency & Percentage \\
\hline T-A & 28 & 29.17 \\
\hline T-B & 29 & 30.21 \\
\hline T-C & 36 & 37.50 \\
\hline T-D & 3 & 2.31 \\
\hline Total & 96 & 100.00 \\
\hline
\end{tabular}

accounts for $17.39 \%$ of the cases ( $p=0.1431$, not significant) (Table 1). Among the patients with luminal $A$ breast cancer, a pCR in the breast (Sataloff's T-A) was observed in five of them, which represents $17.24 \%$ of cases. Conversely, in no patient was no therapeutic effect observed (Sataloff's T-D). In 11 patients (37.93\%), the observed response was higher than $50 \%$ (Sataloff's T-B), while in 13 subjects (44.83\%) it was lower than $50 \%$ (Sataloff's T-C) (Table 2). In the axilla, of a total of 29 patients, $16(55.17 \%)$ continued to have metastatic involvement without changes secondary to the chemotherapy treatment (N-D); in $2(6.90 \%)$, metastasis persisted but treatment-associated changes were observed $(\mathrm{N}-\mathrm{C})$, and only in 4 of them (13.79\%), metastatic disease disappearance with evident chemotherapy-associated changes was observed (N-A) and in 7 of them (24.14\%), no chemotherapy-associated changes or metastases were found (N-B) (Table 3). In those patients with luminal $\mathrm{B}$ breast cancer, pathologic response was complete in the breast (T-A) in 5 of them (17.86\%), while in the axilla, out of a total of 28 , only in $4(14.29 \%)$ was pCR observed (N-A). In contrast, there was no response either in the breast or the axilla (T-D, N-D) in three 


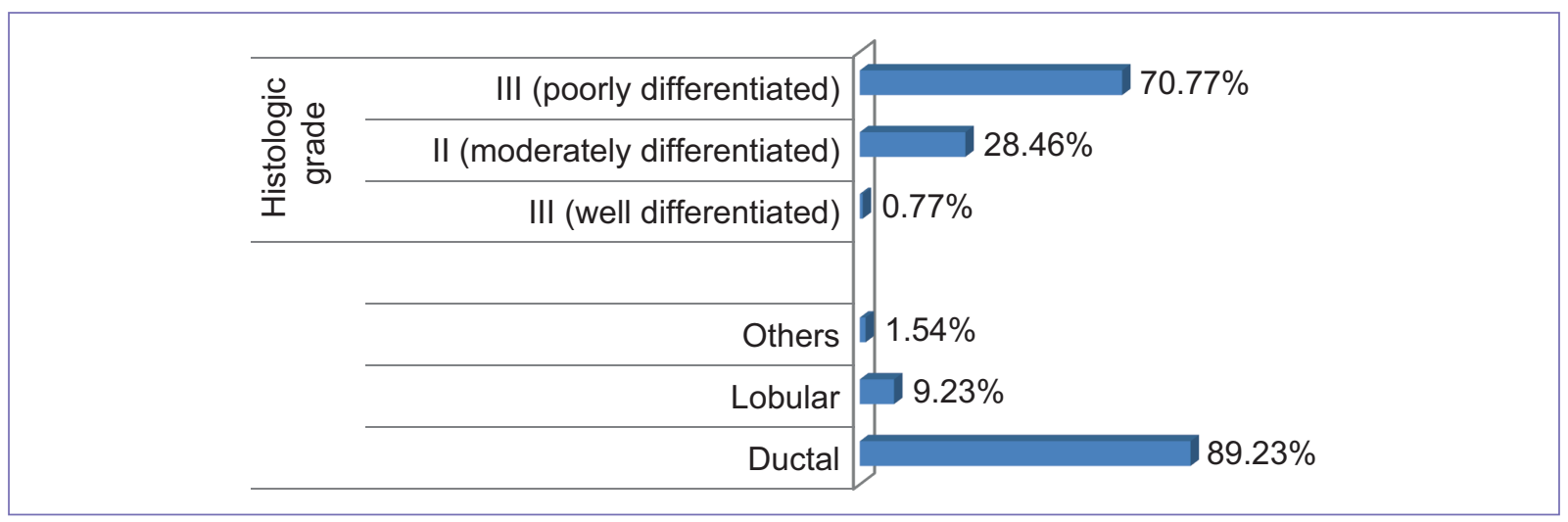

Figure 2. Percentage of breast cancer-diagnosed patients who received adjuvant treatment by histologic grade and type $(n=130)$.

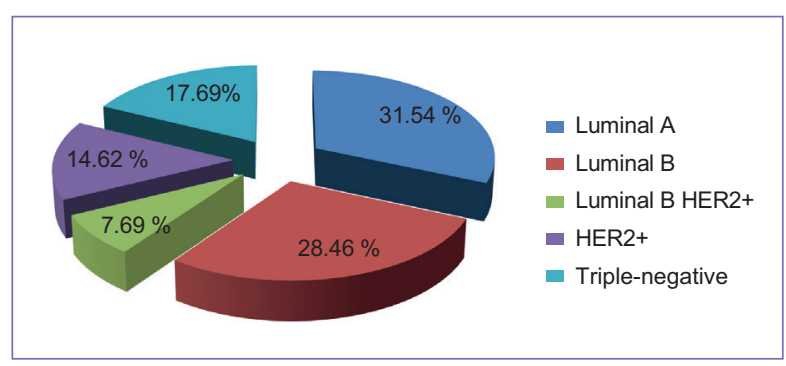

Figure 3. Percentage of breast cancer-diagnosed patients who received adjuvant treatment by biological type $(n=130)$.

Table 3. Frequency and percentage of breast cancer-diagnosed patients who received neoadjuvant treatment by axillary $N$ pathologic response $(n=96)$

\begin{tabular}{|l|c|c|}
\hline N pathologic response & Frequency & Percentage \\
\hline N-A & 16 & 16.67 \\
\hline N-B & 30 & 31.25 \\
\hline N-C & 15 & 15.63 \\
\hline N-D & 35 & 36.46 \\
\hline Total & 96 & 100 \\
\hline
\end{tabular}

(10.71\%) and $10(35.71 \%)$ patients, respectively (see Tables 2 and 3 ). In six cases (21.43\%) a response classifiable as T-B according to Sataloff was found in the breast, while in 14 (50.00\%) it was T-C, with this being the most numerous group (see Table 2). In the axilla, seven patients $(25.00 \%)$ had an $\mathrm{N}-\mathrm{C}$ response, and also seven cases $(25.00 \%)$, had an N-B response (Table 3).
In tumors classified as luminal B-HER2+, pathologic response in the breast was complete or almost complete (T-A) in two patients $(28.57 \%)$ versus one $(14.29 \%)$ of a total of seven in the axilla $(\mathrm{N}-\mathrm{A})$. There was no response either in the breast or in the axilla in 0 and $57.14 \%$, respectively. A T-B response was obtained in three patients $(42.86 \%)$. In two patients (28.57\%) a T-C response was observed. In the axilla, the response was $\mathrm{N}-\mathrm{B}$ in one case (14.29\%) and N-C in also in one (14.29\%). Patients with HER2+ tumors had a T-A pCR in $60 \%$ of cases versus $20 \%$ that obtained a T-B response (9 patients vs. 3 ). In addition, $20 \%$ had a T-C response and no cases of T-D response were observed. In the axilla, of a total of 15 cases, $4(26.67 \%)$ reached an $\mathrm{N}-\mathrm{A}$ pCR, 7 (46.67\%), a N-B response and only 2 (13.33\%), a $\mathrm{N}-\mathrm{C}$ response. Also in two cases (13.33\%), there was a lack of response to systemic treatment observed in the axilla (N-D). With regard to triple-negative cases, response in the breast was complete or almost complete in seven patients $(41.18 \%)$, versus three $(17.65 \%)$ in the armpit. In no patient was there no response in the breast (T-D), while in the axilla, absence of response (N-D) was found in three cases (17.65\%). In six patients (35.29\%), a T-B response was obtained in the breast, while in four subjects, (23.53\%) the response was T-C. As for the axilla, eight patients (47.06\%) had a response classifiable as $\mathrm{N}-\mathrm{B}$, in comparison with three (17.65\%) in whom the response was classified as N-C. Differences in the $\mathrm{T}$ pathologic response rate in the breast are statistically significant for the different molecular phenotypes ( $p=0.0323$ ), with no significant differences being found in the axillary $\mathrm{N}$ pathologic response rate $(p=0.1951)$. 
Table 4. Frequency and percentage of breast cancer-diagnosed patients who received neoadjuvant treatment by received treatment regimen $(n=130)$

\begin{tabular}{|l|c|c|}
\hline Treatment regimen & Frequency & Percentage \\
\hline AC & 30 & 23.08 \\
\hline AC + taxane & 69 & 53.08 \\
\hline AC + taxane + trastuzumab & 16 & 12.31 \\
\hline AC + platinum + taxane & 8 & 6.15 \\
\hline Platinum + taxane + trastuzumab & 1 & 0.77 \\
\hline Aromatase inhibitor & 5 & 3.85 \\
\hline Tamoxifen & 1 & 0.77 \\
\hline Total & 130 & 100.00 \\
\hline
\end{tabular}

AC: Adriamycin + Cyclophosphamide

According to our findings, in all breast cancer molecular phenotypes, higher rates of pathologic response were observed in the breast in comparison with those obtained in the axilla. Differences in the clinical and pathologic response rate in breast $T$ were found to be statistically significant according to whether the treatment was complete or not $(p<0.05)$, with no significant differences in the pathologic response rate in axillary $\mathrm{N}$ being found $(p>0.05)$. Significant differences were also found for the different treatment regimens according to whether the treatment was complete or not $(p=0.005)$ (Table 4). Differences in the pathologic response rate are not statistically significant for the different tumor grades except for clinical response $(p<0.05)$. According to the different analyzed clinical stages, significant differences were observed in the clinical and pathologic axillary $N$ response rate $(p<0.05)$ except for the pathologic breast $T$ response $(p>0.05)$. When establishing the relationship between the different clinical responses studied and breast $\mathrm{T}$ and axillary $\mathrm{N}$ pathologic responses, a statistically significant difference was found between both types of responses $(p<0.05)$.

\section{Discussion}

The predominant overall tumor response (T-C: therapeutic effect lower than $50 \%$ ) is correlated with clinical partial response, which numerically dominated (43.85\%), although it is important noting that complete tumor response is less common than clinical complete response findings due to the low negative predictive value rate the RECIST criteria have in comparison with Sataloff's criteria. The predominance of age in patients undergoing neoadjuvant treatment shows a parallel relationship with the age interval of breast cancer peak incidence (41 to 60 years) $)^{2}$. In general, no predominance of clinical and pathologic complete response was found with neoadjuvant treatment. This is relevant, because although neoadjuvant chemotherapy has not been shown to increase overall survival or disease-free interval, in general it has shown to increase survival in patients with $\mathrm{pCR}$ in comparison with those with pathologic responses that show residual tumor. Consistently with the aforementioned bibliographic references, we have found a high rate of pathologic complete responses in HER2+ and triple-negative tumors and a low rate of complete responses with luminal tumors, which reveals the high chemosensitivity of tumors with negative hormone receptors and the resistance of luminal tumors.

In general, breast T-A pCR was found to be significantly higher in comparison with axillary N-A, as in many international studies, although the cause of this behavior after chemotherapy has not yet been investigated. In our study, the pathologic response found in axillary lymph nodes was generally lower than that found in the general literature $(20 \%$ to $60 \%)$, which may be due to the stage at which most patients arrive (nearly $60 \%$ at stage III). Significant differences $(p<0.05)$ were also found in the rates of breast $\mathrm{T}$ clinical and pathological response and in the treatment regimens according to whether the treatment was completed or not. The low rates of pathologic complete responses (T-A) might be due to the fact that a large percentage of patients did not receive the appropriate treatment regimen according to the tumor molecular biology and that in many cases treatment was not completed.

\section{Conclusion}

In this work, clinical partial response was found more frequently $(43.85 \%)$, followed by clinical complete response (34.62\%), incomplete response (12.31\%) and progressive disease $(9.23 \%)$. In the anatomic pathology evaluation, T-C $(37.5 \%)$ was more commonly found, followed by T-B (30.21\%), T-A (29.17\%) and T-D (2.31\%). Pathological response in the breast was higher than that found in the axilla. As for response-predictive variables, we found that the HER2+ and triple-negative molecular subtypes had a higher response rate than the luminal subtypes, and whether the treatment received was entirely administered or not also had an influence. 


\section{References}

1. Yoffe de Quiroz I. Cáncer de mama. Tesis. Aspectos Clínicos epidemiológicos y terapéuticos en pacientes paraguayas.Asunción:1996.

2. Patel S, Buzdar A. Cáncer de seno en estado inicial y localmente avanzado. En: Vásquez O, Santa Cruz G. Manual de Oncología Médica MD Anderson. Vol. II. 2. ${ }^{\text {a }}$ ed. Estados Unidos: AMOLCA; 2014.

3. Aguilar A, Álvarez A, Armanasco E, Azar M, Berman G, Cáceres V, et al. Tumores de mama. En: Dortencio A, Babini L, Zappulla M, et al., editores. Pautas en Oncología. Diagnóstico, tratamiento y seguimiento del cáncer. Buenos Aires: Instituto Angel H. Roffo; 2015.

4. Edge SB, Byrd DR, Carducci MA, Compton CC, editores. American Joint Committee on Cancer (AJCC) Cancer Staging Manual. $7^{\text {th }}$ ed. New York, NY: Springer; 2009

5. Sobin LH, Gospodarowicz MK, Wittekind $\mathrm{CH}$, editores. International Union against Cancer (UICC): TNM classification of malignant tumors $7^{\text {th }}$. Oxford; 2009.

6. Lakhani SR, Ellis IO, Schnitt SJ, Tan PH, van de Vijver MJ, editores. World Health Organization (WHO) Classification of Tumours of the Breast. Lyon, France: IARC Press; 2012.

7. Cresta C, González E, Noblía C, Azar M, Armanasco E, Montoya D, et al. Tumores de mama. En: Kirchuk R, Zerga M, et al., editores. Pautas en Oncología. Diagnóstico, tratamiento y seguimiento del cáncer. Buenos Aires: Instituto Angel H. Roffo; 2012.

8. Prat A, Perou CM. Deconstructing the molecular portraits of breast cancer. Mol Oncol. 2011;5:5-23.

9. Cuzick J, Dowsett M, Pineda S, Wale C, Salter J, Quinn E, et al. Prognostic value of a combined estrogen receptor, progesterone receptor, $\mathrm{Ki}-67$, and human epidermal growth factor receptor 2 immunohistochemical score and comparison with the Genomic Health recurrence score in early breast cancer. J Clin Oncol. 2011;29:4273-8.

10. Goldhirsch A, Winer EP, Coates AS, Gelber RD, Piccart-Gebhart M, Thürlimann B, et al.; Panel members. Personalizing the treatment of women with early breast cancer: highlights of the St Gallen International Expert Consensus on the Primary Therapy of Early Breast Cancer 2013. Ann Oncol. 2013;24(9):2206-23.

11. Guiu S, Michiels S, André F, Cortes J, Denkert C, Di Leo A, et al. Molecular subclasses of breast cancer: how do we define them? The IMPAKT 2012 Working Group Statement. Ann Oncol. 2012;23:2997-3006.

12. Geyer F, Weigelt B, Reis-Filho J, Reis-Filho JS. Molecular classification of estrogen receptor-positive/luminal breast cancers. Adv Anat Pathol. 2012;19:39-53

13. Prat A, Cheang MC, Martin M, Parker JS, Carrasco E, Caballero R, et al. Prognostic significance of progesterone receptor-positive tumor cells within immunohistochemically defined luminal A breast cancer. J Clin Oncol. 2013;31(2):203-9.

14. Klein M, Dabbs D, Shuai Y, Brufsky A, Jankowitz R, Puhalla S, et al. Prediction of the Oncotype DX recurrence score: use of pathology-generated equations derived by linear regression analysis. Mod Pathol. 2013; 26(5): 658-64.

15. Lehmann B, Bauer J, Chen X, Sanders M, Chakravarthy A, Shyr Y, et al. Identification of human triple-negative breast cancer subtypes and preclinical models for selection of targeted therapies. J Clin Invest. 2011; 121(7):2750-67.

16. Metzger-Filho O, Tutt A, de Azambuja E, Saini K, Viale G, Loi S, et al. Dissecting the heterogeneity of triple negative breast cancer. J Clin Oncol. 2012;30:1879-87.

17. Gazinska P, Grigoriadis A, Brown JP, Millis RR, Mera A, Gillett C, et al. Comparison of basal-like triple-negative breast cancer defined by morphology, immunohistochemistry and transcriptional profiles. Mod Pathol. 2013;26(7):955-66.

18. Hammond ME, Hayes DF, Dowsett M, et al. American Society of Clinical Oncology/College of American Pathologists guideline recommendations for immunohistochemical testing of estrogen and progesterone receptors in breast cancer. Arch Pathol Lab Med. 2010;134(6):907-22.
19. Dowsett M, Nielsen TO, A'Hern R, et al. Assessment of Ki67 in breast cancer: recommendations from the International Ki67 in Breast Cancer Working Group. J Natl Cancer Inst. 2011;103(22):1656-64.

20. Wolff AC, Hammond ME, Allison KH, Harvey BE, Mangu PB, Bartlett JMS, et al. Human epidermal growth factor receptor 2 testing in breast cancer: American Society of Clinical Oncology/College of American Pathologists clinical practice guideline update. J Clin Oncol. [ internet]. 2018. 18 julio 2018]; 36(20):2105-22. Disponible en: https://www.ncbi.nlm.nih.gov/pub$\mathrm{med} / 29846122$

21. Mathew J, Asgeirsson KS, Cheung KL, Chan S, Dahda A, Robertson JF. Neoadjuvant chemotherapy for locally advanced breast cancer: A review of the literature and future directions. Eur J Surg Oncol. 2009;35:113-22.

22. Román A, Alvarez C, Hardisson D, García F, Sánchez J. Evaluación de la respuesta patológica a la quimioterapia neoadyuvante en mama y axila según los fenotipos moleculares del cáncer de mama. Rev Senol Patol Mamar. 2016;29(3):120-24.

23. Portellez Cruz A, Rodríguez Alberteris $Y$, Fernández Sarabia $P$, Sanz Pupo N, Oller Pousada J. Quimioterapia neoadyuvante en cáncer de mama, localmente avanzado. CCM. 2013;17(4):433-42.

24. Jiménez-Ballvé A, Serrano-Palacio A, García-Sáenz JA, Ortega-Candil A, Salsidua-Arroyo O, Román-Santamaría JM, et al. Axillary pathologic response after neoadjuvant chemotherapy in locally advanced breast cancer with axillary involvement. Rev Esp Med Nucl Imagen Mol. 2015;34(4):230-5.

25. Ayala de la Peña $F$, de la Morena Barrio $P$, Fernández Sánchez A, Ivars Rubio A. $38^{\text {th }}$ Annual San Antonio Breast Cancer Symposium. Resumen de las aportaciones más relevantes. Rev senol patol mamar. 2016;29(2): 75-82.

26. Díaz-Expósito R, Marti-Bonmati L, Burgués O, Casáns-Tormo I, Bermejo-de las Heras B, Julve-Parreño A, et al. Detección selectiva del ganglio centinela tras administración intratumoral del radiotrazador, en pacientes con cáncer de mama tratadas con quimioterapia neoadyuvante en relación con el grado de respuesta tumoral. Rev Española de Med nuclear e imagen molecular. [internet]. 2016. [citado 21 diciembre 2016];35(6): 358-64. Disponible en: https://www.journals.elsevier.com/revista-espanola-de-medicina-nuclear-e-imagen-molecular.

27. López Carpintero, Sánchez Méndez, De Santiago García. Cáncer de mama con Her-2-neu y receptores hormonales positivos. Quimioterapia neoadyuvante, biopsia de ganglio centinela y tratamiento hormonal. Ginecol Obstet Mex. 2012;80(11):720-4

28. Brugués Ricardo, Guzmán Luis Hernán, Sánchez Oswaldo, Díaz Sandra, Vergara Édgar. Neoadyuvancia en cáncer de mama. Rev Colomb Cancerol. 2009;13(3):157-74.

29. Melo-Sánchez S, Gelvez-Parra L, Osma-Zambrano S. Clasificación inmunohistoquímica del cáncer de mama y su importancia en el diagnóstico, pronóstico y enfoque terapéutico. MedUNAB. 2016;18(3):193-203.

30. Marcos de Paz LM, Tejerina Bernal A, Arranz Merino ML, Calvo de Juan V. Resonancia magnética de mama: cambios en la imagen del cáncer tratado con neoadyuvancia. Correlación con subtipos moleculares. Radiologia. 2012;54(5):442-8.

31. Cruz Ciria S, Jiménez Aragón F, García Mur C, Estteban Cuesta H, Gros Bañeres $\mathrm{B}$. Resonancia magnética en el cáncer de mama tratado con neoadyuvancia: correlación radiopatológica de la respuesta y supervivencia libre de enfermedad en función del subtipo molecular. Radiologia. 2014;56(6):524-32.

32. Román Guindo, Martí Álvarez, Hardisson Hernáez, De Santiago García, Francisco Javier, Sánchez Méndez. Evaluación de la respuesta patológica a la quimioterapia neoadyuvante en mama y axila según los fenotipos moleculares del cáncer de mama. Rev senol patol mamar. 2016;29(3):120-4.

33. Vázquez T, Krygier G, Barrios E, Cataldi S, Vázquez A, Estellano F, et al. Análisis de Sobrevida de una población con cáncer de mama y su relación con factores pronósticos: estudio de 1311 pacientes seguidas durante 230 meses. Rev Med Uruguay. 2005;vol(21):107-21.

34. De Mestral E. Bioética e investigación científica. En: De Mestral E.: Manual de Bioética. 2. ${ }^{a}$ Ed. Asunción: EFACIM; 2009. 